\title{
Overall Financial Status with Reference to Noble Consolidated Glazings
}

\author{
M.Sinduja, J Pavithra, K.Venkatraman
}

\begin{abstract}
A Study on the financial performance of the NOBLE CONSOLIDATED GLAZINGS LIMITED is intended to examine the current practices of financial performance. Hence, financial analysis is the starting point for making plans, before using any sophisticated forecasting and planning procedures. Understanding the past is a prerequisite for anticipating in future.

The ways in which ratio analysis can help in long - range planning, budgeting, and asset management to strengthen financial performance and help avoid financial difficulties is explained. Types of ratios considered include balance sheet ratios, liquidity ratio, profitability ratio, proprietary ratios.

The ability of an organization to analyze its financial position is essential for improving its competitive position in the market place. Through a careful analysis of its financial performance, the organization can identify opportunities to improve performance at the department, unit, or organizational level.
\end{abstract}

Keywords : Google AdWords, billboard, online marketing

\section{INTRODUCTION}

Online advancement is a showcasing technique that includes the utilization of the Internet as a medium to get site traffic and target and convey promoting messages to the correct clients. Online advancement is designed for characterizing markets through one of a kind and helpful applications. [1],[ 3],[5]Presently multi day use of Internet is higher levels. Web based shopping and deals are making a benefit it fast. Initial one is making a great site and host it on the web. Social medias like (Facebook, Tweeter, Instagram and google+) are additionally valuable to make an advancement in various structure. [2 ],[ 4],[6]

There are four fundamental sorts of advancement:

\section{1) Advertising}

2) Sales Promotion

3) Personal Selling

Monetary Analysis is the way toward distinguishing the money related quality and shortcoming of a firm from the accessible bookkeeping information and fiscal reports. The primary taste of money related examiner is to decide the data

\section{Revised Manuscript Received on July 22, 2019.}

M.Sinduja , Department of MBA,Bharath institute of Higher Education \& Research,Tamilnadu,India Email:sinduja@gmail.com

Ms. J Pavithra, Assistant Professor,Department of MBA,Bharath institute of Higher Education \& Research,Tamilnadu,India Email pavithralect@yahoo.com

K.Venkatraman, Department of Civil Engg,,Bharath institute of Higher Education \& Research,Tamilnadu,India applicable to the choice under thought from the all out data contained in the fiscal summaries. A business can't run productively on the off chance that it doesn't have satisfactory money to meet its necessities.

Business execution is the aftereffect of numerous individual choices made constantly by the board. To evaluate the business execution one needs to break down the budgetary and monetary impacts of these choices and judge the outcome through money related examination systems. Money related investigation is a successful device of monetary arranging. It is a strategy which features the monetary development of an association.

Those people who are not associated with the undertaking make it. They don't approach the venture. They primarily rely upon distributed articulations. The speculator's credit organizations and research researchers make such kind of examination. Those people who approach the books of records make the inward investigation. They are individuals from the association. Examination of budget summaries or other monetary information for administrative reason for existing is the inner kind of investigation.

The Financial Analysis job performs top to bottom investigation of the foundation's money related and working outcomes in rivalry of the specialty units and gets ready administration data for Senior Management and the Board. A money related foundation performs by budgetary examination on bookkeeping information and in administration data to evaluate business patterns, venture needs and liquidity levels. A monetary organization what's more may examine budget reports to check capital necessities and may confirm that these prerequisites meet dictator esteems. an assortment of representatives interface in money related investigation, including bookkeepers, monetary experts, charge pros, speculation chiefs and corporate account staff. This job of Financial Analysis is ordinarily found as a different unit just in bigger budgetary establishments. Following is uncovered

4) Publicity. [7],[ 9] ,[11]

\section{SCOPE OF THE STUDY}

This study which is done at Noble Consolidated Glazings Ltd aims at studying Overall Financial Status from (2007 - 2008, $2008-2009,2009-2010$ )

This study aims at analyzing six headings of the company that are ratio analysis, working capital, funds flow analysis, cash flow analysis, comparative statement and trend analysis. The study would help the company to know their financial status and helps to make the financial decision making process. [8],[ 10],[12] 


\section{RESULTS OF THE STUDY}

- Figures for the analysis are taken from the annual reports. So all the limitations of their statements are applied to the study.

- It is very to know the whole transaction methods that are followed in NCGL. [13], [15] ,[ 17]

- The major part of the work is concerned with financial data

Table 1. Showing Quick Ratio

\begin{tabular}{|l|l|l|l|}
\hline ITEMS & $\mathbf{2 0 0 7 - 2 0 0 8}$ & $\mathbf{2 0 0 8 - 2 0 0 9}$ & $\mathbf{2 0 0 9 - 2 0 1 0}$ \\
\hline Liquid Assets & 92311815 & 223993630 & 398691790 \\
\hline Current Liabilities & 52141655 & 156201985 & 121616755 \\
\hline Quick Ratio & $\mathbf{1 . 7 7 0}$ & $\mathbf{1 . 4 3 3}$ & $\mathbf{1 . 8 7 5}$ \\
\hline
\end{tabular}

\section{Chart 1 Showing Quick Ratio}

For The Year 2007 - 2008, 2008 - 2009 And 2009 - 2010

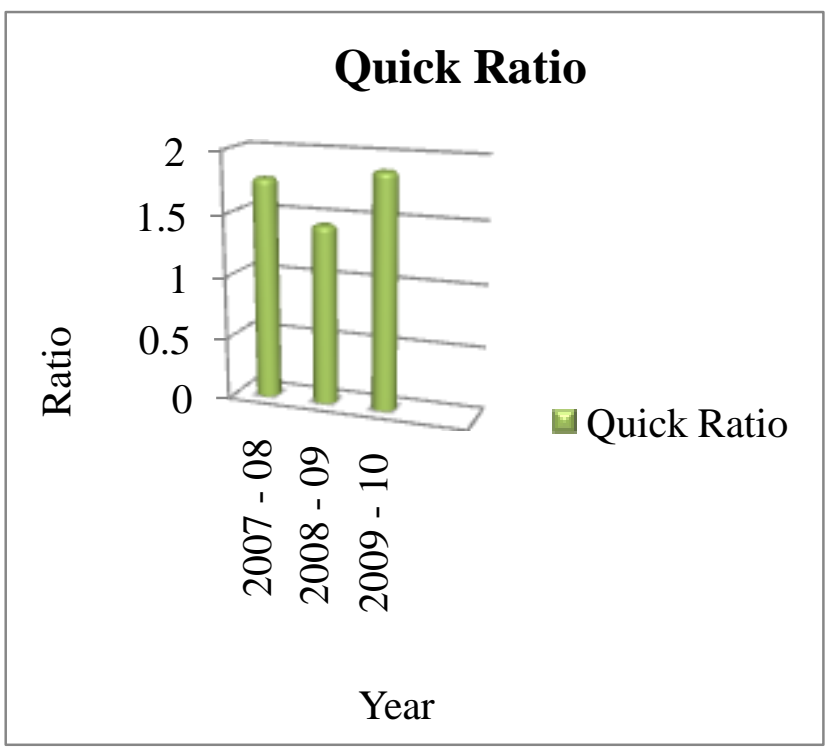

The quick was high during the year 2010. This indicates that the company has utilized the liquid assets and current liabilities efficiently during that year. The liquid assets are increasing year by year comparing to the current liabilities. The quick ratio was 1.875 times in 2010 and in past two years it was decreased. [20],[22], [24]

\section{Proprietary Ratio :}

\section{Proprietary Ratio \\ $=$ Shareholder's Funds / Total}

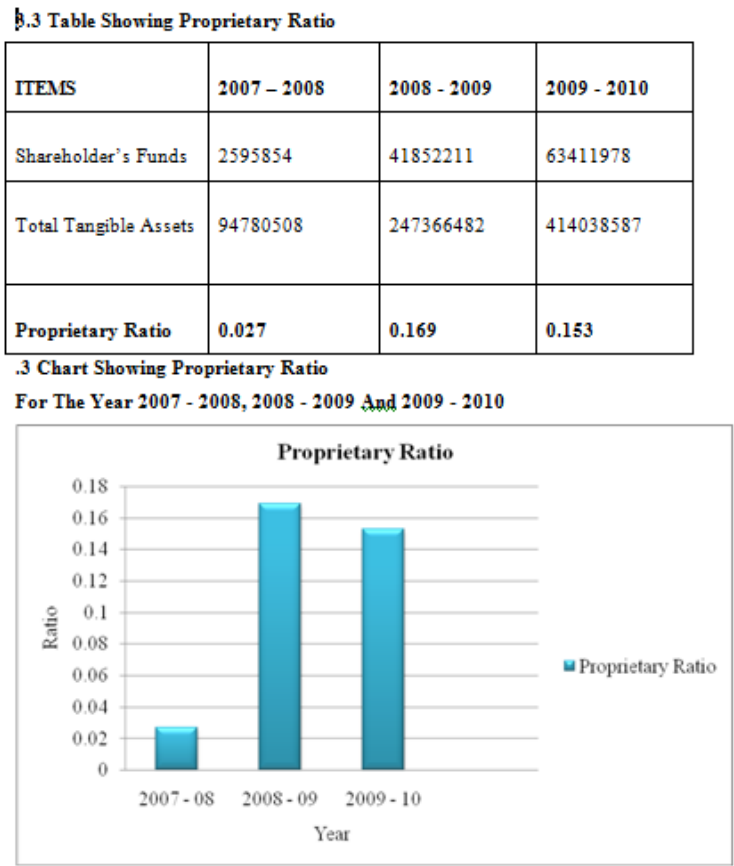

In the year 2008 the proprietary ratio is 0.027 times and it raises in 2009 to $0.169 \%$ times and in 2010 it falls to 0.153 times it shows the company ratio. The total tangible assets are higher than the shareholder's fund so the quick ratio was high in 2008 and it has been decreased in other two years. [14],[ 16], [18]

\section{Profitability Ratio : \\ Profitability Ratio \\ Employed * 100}

= Operating Profit $/$ Capital

Table 3:Showing Profitability Ratio

\begin{tabular}{|l|l|l|l|}
\hline ITEMS & $\mathbf{2 0 0 7 - 2 0 0 8}$ & $\mathbf{2 0 0 8 - 2 0 0 9}$ & $\mathbf{2 0 0 9 - 2 0 1 0}$ \\
\hline Operating Profit & 4936515 & 8664490 & 12132269 \\
\hline Capital Employed & 92742893 & 238701992 & 401906318 \\
\hline Profitability Ratio & $\mathbf{5 . 3 2 2}$ & $\mathbf{3 . 6 2 9}$ & 11.905 \\
\hline
\end{tabular}

5.4 Chart Showing Profitability Ratio

For The Year 2007 - 2008, 2008 - 2009 And 2009 - 2010 


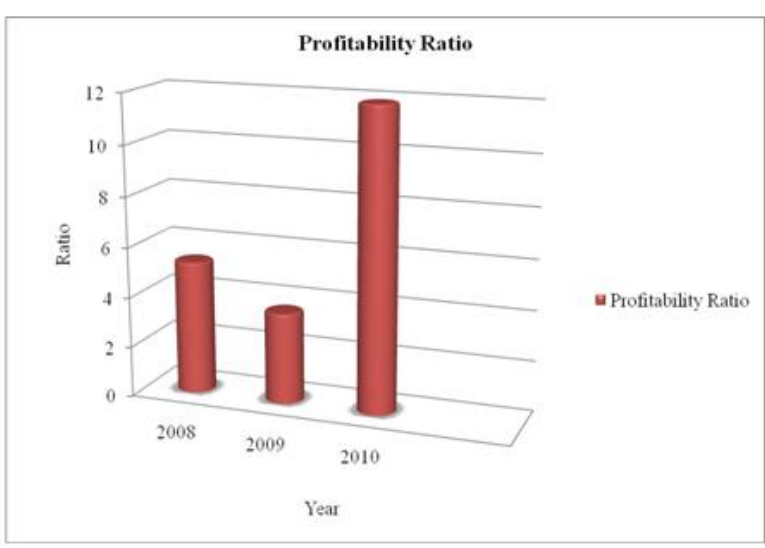

Fig 3: Showing Profitability Ratio

In the year 2008 the profitability ratio was $5.322 \%$ and it falls in 2009 to $3.629 \%$ and in 2010 it raises to $11.905 \%$ it shows the ups and down in profitability ratio. The operating profit increases year by year comparing with capital employed. The profitability also increases year by year. [26],[28],[30]

\section{WORKING CAPITAL}

Table 4 Showing The Statement Working Capital For The Year 2007 - 2008 \& 2008 - 2009

\begin{tabular}{|c|c|c|c|c|}
\hline Item & $2007-2008$ & $2008-2009$ & Incresse $(+)$ & Decrease (-) \\
\hline Correat Asnes: & & & & \\
\hline $\begin{array}{l}\text { Coctract Woth in } \\
\text { Progress }\end{array}$ & 79001745 & 220183960 & 38312735 & - \\
\hline $\begin{array}{l}\text { Cash \& Bank } \\
\text { bolagese }\end{array}$ & 945553 & 3291623 & 2346070 & \\
\hline Losas \& A Átaces & 12534517 & 9513047 & - & 2331470 \\
\hline Ceresent Labbihies: & & & & \\
\hline $\begin{array}{l}\text { Corrent Labinats \& } \\
\text { Provision }\end{array}$ & 47205140 & 147357495 & 100332355 & - \\
\hline $\begin{array}{l}\text { Provition for } \\
\text { axatise }\end{array}$ & 4936515 & 8664490 & 3727975 & \\
\hline $\begin{array}{l}\text { Iescesse in morking } \\
\text { capial }\end{array}$ & & & & 162367715 \\
\hline Total & & & 165219185 & 165219185 \\
\hline
\end{tabular}

TREND PERCENTAGES

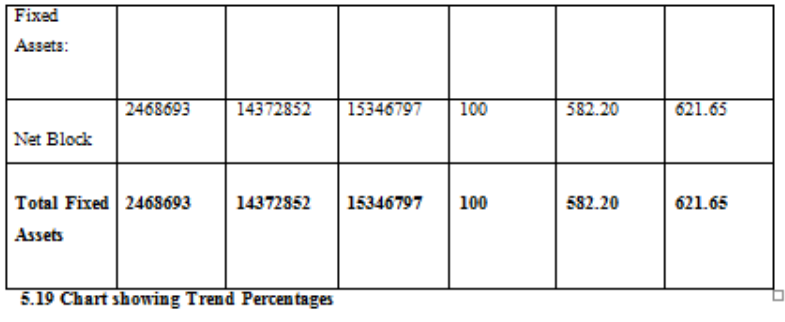

For The Year 2008, 2009 and 2010

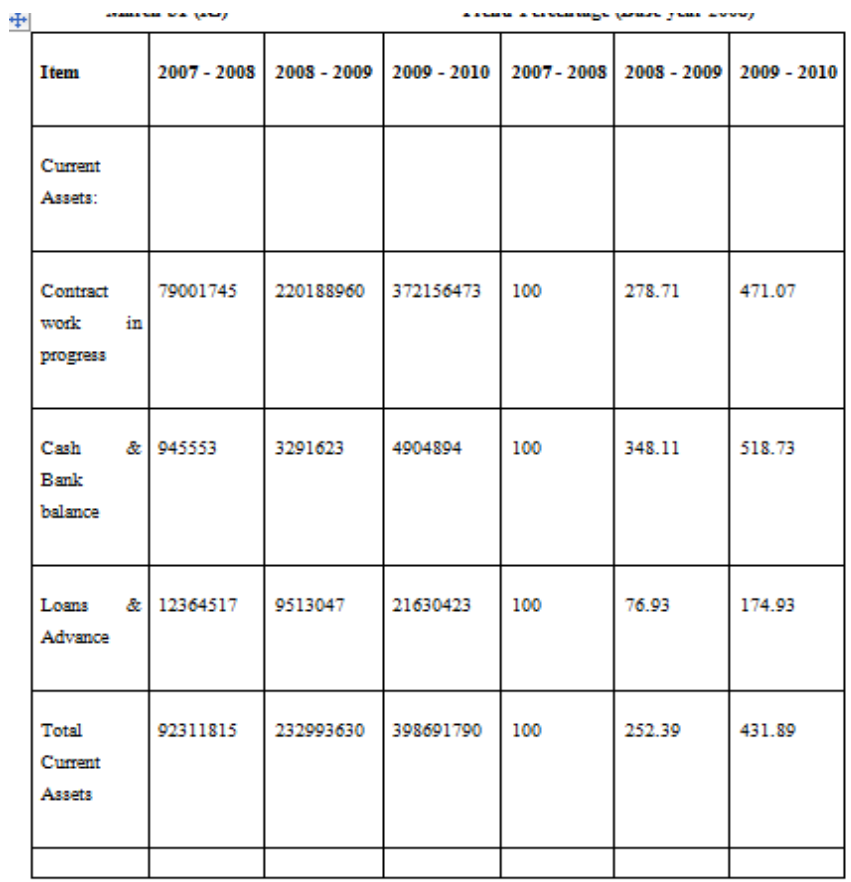

Fig 4:showing Trend Percentages

For The Year 2008, 2009 and 2010

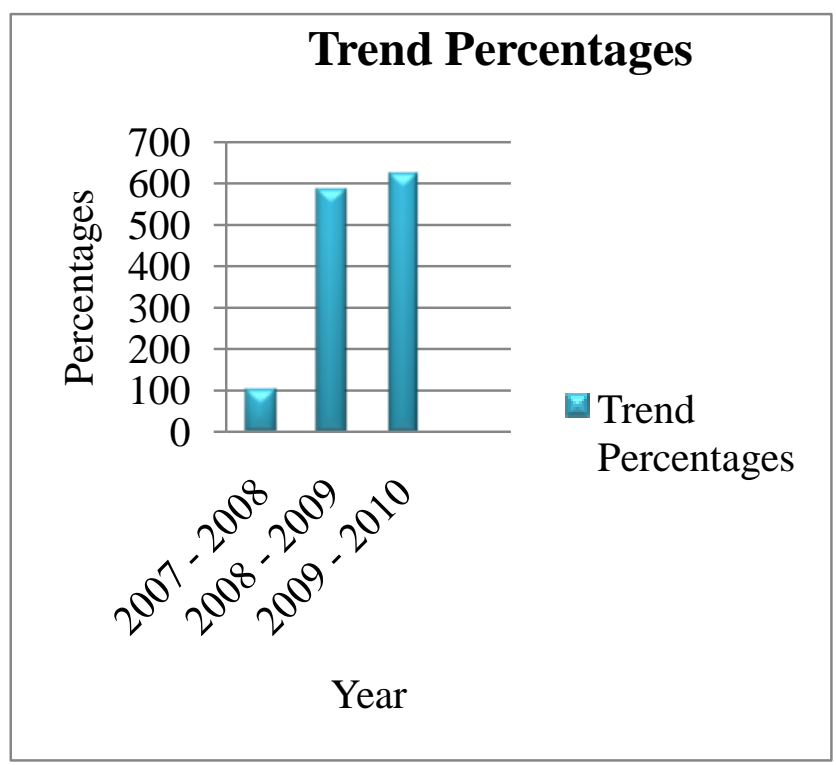

The sales have been increased drastically from the year 2008 to 2010 and the total assets of the company were also increased. It has increased due to current assets and fixed assets. [31],[33] 


\section{CONCLUSION}

The study on the financial performance analysis of the Noble Consolidated Glazings Ltd highlights the financial strength and weakness of the company. The analysis shows that the company was performing well in past three years. It is found that the turnover during the three year period has increased continuously. The current assets of the company have increased and current liability has increased.

Analyzing the company's balance sheet for the past three years, it is found that there was increase in reserves and surplus. This is due to increase in net profit. This study indicates how important is to allocate and utilize funds effectively.

\section{REFERENCES}

1) BharthVajan R., Ramachandran S.,Psychographic dimensions of training,2016,International Journal of Pharmacy and Technology,V-8,I-4,P-23727-23729

2) Balakrishnan P., Bharthvajan R.,A study on human resource planning in hospitals in Chennai City,2014,International Journal of Applied Engineering Research,V-9,I-22,P-7503-7507

3) Priyadarsini P., Bharthvajan R.,Role of emotional intelligence training programme in reducing the stress of the nurses,2014,International Journal of Applied Engineering Research,V-9,I-22,P-7411-7421

4) Kerinab Beenu G., Bharthvajan R.,Empirical analysis on the cosmetic buying behavior of young women in South India,2014,International Journal of Applied Engineering Research,V-9,I-22,P-7361-7366

5) Balakrishnan P., Bharthvajan R.,Whistling in the wind,2014,International Journal of Applied Engineering Research,V-9,I-22,P-7586-7593

6) Krishnan B., Peter M.,Health hazards of Indian Bpo employee-an alarming issue,2014,International Journal of Applied Engineering Research,V-9,I-22,P-7336-7341

7) Kerinab Beenu G.H., Peter M.,Role of insurance in economic development,2014,International Journal of Applied Engineering Research,V-9,I-22,P-7532-7539

8) Balakrishnan P., Peter M., Priyadarsini P.,Efficiency of safety measures for wellbeing of employees in manufacturing industry,2014,International Journal of Applied Engineering Research,V-9,I-22,P-7376-7382

9) Anbarasi M., Praveen Kumar S.,Online sales promotions of herbal products and its effectiveness towards tanisha.com,2019,Indian Journal of Public Health Research and Development,V-10,I-1,P-195-200

10) Anbarasi M., Praveen Kumar S.,Various online marketing and promotions strategies to improve the validation towards the organic products in the pharmaceutical sectors,2019,Indian Journal of Public Health Research and Development, V-10,I-1,P-263-269

11) Loganathan R., Praveen Kumar S.,Grievance handling a key factor for solving issues of employees in an organization,2014,International Journal of Applied Engineering Research,V-9,I-22,P-7483-7491

12) Loganathan R., Praveen Kumar S.,Study on preference of private label brands in super and Hypermarkets,2014,International Journal of Applied Engineering Research,V-9,I-22,P-7327-7335

13) Smitha M., Praveen Kumar S.,Understanding stress and its managementamong the nurses in Chennai city,2014,International Journal of Applied Engineering Research,V-9,I-22,P-7560-7565

14) Kerinab Beenu G.H., Praveen Kumar S.,A study on the investment behavior of Chennai investors in mutual fund schemes,2014,International Journal of Applied Engineering Research,V-9,I-22,P-7520-7525

15) Loganathan R., Praveen Kumar S.,Retention strategies key for organizational productivity,2014,International Journal of Applied Engineering Research,V-9,I-22,P-7443-7447

16) Pavithra J., Ganesan M., Brindha G.,State wise analysis of microfinance sector in India,2016,International Journal of Pharmacy and Technology,V-8,I-4,P-23417-23432

17) Pavithra J., Ganesan M.,A comparative study on microfinance in India and abroad,2016,International Journal of Applied Business and Economic Research,V-14,I-8,P-5471-5476

18) Pavithra J., Ganesan M.,A study on awareness and impact of micro-financial schemes,2016,International Journal of Applied Business and Economic Research,V-14,I-8,P-5449-5460
19) Senthilmurugan P., Pavithra J.,Consumer preference towards organised retailing with reference to Big Bazaar,2014,International Journal of Applied Engineering Research,V-9,I-22,P-7469-7475

20) Senthilmurugan P., Pavithra J.,Implication of social media marketing in growing healthcare industry,2014,International Journal of Applied Engineering Research,V-9,I-22,P-7448-7456

21) Loganathan R., Pavithra J.,Consumer perception towards private label brand over other brands in super markets and hypermarkets,2014,International Journal of Applied Engineering Research,V-9,I-22,P-7355-7360

22) Kerinab Beenu G., Pavithra J.,Tradeâ€"off between liquidity and profitability in logistics industry,2014,International Journal of Applied Engineering Research,V-9,I-22,P-7398-7401

23) Kerinab Beenu G., Pavithra J.,A study on the prospective consumerâ€ $€^{\mathrm{TM}_{S}}$ perception towards utility cars in Chennai city,2014,International Journal of Applied Engineering Research,V-9,I-22,P-7526-7531

24) Pavithra J., Dilli Babu P., Ambuli T.V.,A study on budgetary control at Maruti Service Masters, Chennai,2014,International Journal of Applied Business and Economic Research,V-12,I-2,P-151-161

25) Pavithra J., Dilli Babu P., Ambuli T.V.,A study on customer satisfaction of retro Garments Pvt Ltd, Chennai,2014,International Journal of Applied Business and Economic Research,V-12,I-2,P-381-391

26) Kerinab Beenu G.H., Pavithra J., Senthilmurugan P.,A study on the influence of promotional activities for TATA ARIA among consumers in Chennai,2014,International Journal of Applied Engineering Research,V-9,I-22,P-7572-7578

27) Vijayaragavan S.P.,An investigative expert that's general FBG sensors,International Journal of Mechanical Engineering and Technology,V-8,I-8,PP-1500-1505,Y-2017

28) Vijayaragavan S.P.,Equalization routing protocol for Wi-Fi sensor strategy,International Journal of Mechanical Engineering and Technology,V-8,I-8,PP-1662-1666,Y-2017

29) Karthik B., Kiran Kumar T.V.U., Vijayaragavan P., Bharath Kumaran E.,Design of a digital PLL using 0.35 $\hat{\mathrm{I}}^{1} / 4 \mathrm{~m}$ CMOS technology,Middle East Journal of Scientific Research,V-18,I-12,PP-1803-1806,Y-2013

30) Kanniga E., Selvaramarathnam K., Sundararajan M.,Kandigital bike operating system,Middle - East Journal of Scientific Research,V

31) Jasmin M., Vigneshwaran T., Beulah Hemalatha S.,Design of power aware on chip embedded memory based FSM encoding in FPGA,International Journal of Applied Engineering Research,V-10,I-2,PP-4487-4496,Y-2015

32) Jasmin M.,Optimization techniques for low power VLSI circuits,Middle East Journal of Scientific Research,V-20,I-9,PP-1082-1087,Y-2014

33) Jasmin M., Vigneswaran T.,Fuzzy controller for error control of on - Chip communication,2017 International Conference on Algorithms, Methodology, Models and Applications in Emerging Technologies, ICAMMAET 2017,V-2017-January,I-,PP-1-5,Y-2017

\section{AUTHORS PROFILE}

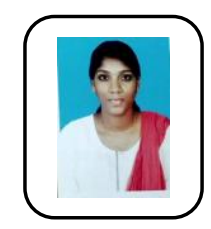

M.Sinduja , Department of MBA,Bharath institute of Higher Education \& Research,Tamilnadu,India

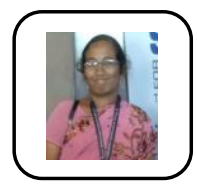

Ms. J Pavithra, Assistant Professor,Department of MBA,Bharath institute of Higher Education \& Research,Tamilnadu,India

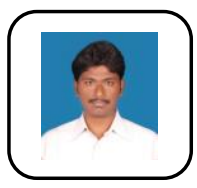

K.Venkatraman, Department of Civil,,Bharath institute of Higher Education \& Research,Tamilnadu,India 